\title{
STATE-OF-THE-ART ELECTRON GUNS AND INJECTOR DESIGNS FOR ENERGY RECOVERY LINACS (ERL) ${ }^{*}$
}

\author{
A.M.M. Todd, ${ }^{1}$ A. Ambrosio, ${ }^{1}$ H. Bluem, ${ }^{1}$ V. Christina, ${ }^{1}$ M.D. Cole,${ }^{1}$ \\ M. Falletta, ${ }^{1}$ D. Holmes, ${ }^{1}$ E. Peterson, ${ }^{1}$ J. Rathke, ${ }^{1}$ T. Schultheiss, ${ }^{1}$ R. Wong, ${ }^{1}$ \\ S. Benson, ${ }^{2}$ E. Daly, ${ }^{2}$ D. Douglas, ${ }^{2}$ F. Dylla ${ }^{2}$ W. Funk ${ }^{2}$ C. Hernandez-Garcia, ${ }^{2}$ \\ J. Hogan, ${ }^{2}$ P. Kneisel, ${ }^{2}$ J. Mammosser, ${ }^{2}$ G.R. Neil, ${ }^{2}$ L. Phillips, ${ }^{2}$ J. Preble, ${ }^{2}$ \\ R. Rimmer, ${ }^{2}$ C. Rode, ${ }^{2}$ T. Siggins, ${ }^{2}$ T. Whitlach, ${ }^{2}$ M. Wiseman, ${ }^{2}$ I. Ben-Zvi, ${ }^{3}$ \\ A. Burrill, ${ }^{3}$ R. Calaga, ${ }^{3}$ P. Cameron, ${ }^{3}$ X. Chang, ${ }^{3}$ H. Hahn, ${ }^{3}$ D. Kayran, ${ }^{3}$ J. Kewisch, ${ }^{3}$ \\ V. Litvinenko, ${ }^{3}$ G. McIntyre, ${ }^{3}$ A. Nicoletti, ${ }^{3}$ J. Rank, ${ }^{3}$ J. Scaduto, ${ }^{3}$ T. Srinivasan-Rao, ${ }^{3}$ \\ K. Yu, ${ }^{3}$ A. Zaltsman, ${ }^{3}$ Y. Zhao, ${ }^{3}$ P. Colestock,${ }^{4}$ J.P. Kelley, ${ }^{4}$ S. Kurennoy, ${ }^{4}$ D. Nguyen, ${ }^{4}$ \\ S. Russell, ${ }^{4}$ W. Reass, ${ }^{4}$ D. Schrage, ${ }^{4}$ R. Wood, ${ }^{4}$ R. Campisi, ${ }^{5}$ D. Janssen,${ }^{6}$ J.W. Lewellen, ${ }^{7}$ \\ V. Nguyen-Tuong, ${ }^{8}$ J. Sekutowicz, ${ }^{9}$ and L. Young, ${ }^{10}$ \\ ${ }^{1}$ Advanced Energy Systems, Medford, NY \\ ${ }^{2}$ JFNAF, Newport News, VA \\ ${ }^{3}$ Brookhaven National Laboratory, Upton, NY \\ ${ }^{4}$ Los Alamos National Laboratory, Los Alamos, NM \\ ${ }^{5}$ Oak Ridge National Laboratory, Oak Ridge, TN \\ ${ }^{6} \mathrm{FZR}$, Dresden, Germany \\ ${ }^{7}$ Argonne National Laboratory, Argonne, $\mathbb{I L}$ \\ ${ }^{8}$ Tunnel Dust, Inc., Newport News, VA \\ ${ }^{9}$ DESY, Hamburg, Germany \\ ${ }^{10}$ TechSource, Santa Fe, NM
}

May, 2005

${ }^{*}$ This manuscript has been authored by Brookhaven Science Associates, LLC under Contract No. DE-AC02-98CH10886 with the U.S. Department of Energy. The United States Government retains, and the publisher, by accepting the article for publication, acknowledges, a world-wide license to publish or reproduce the published form of this manuscript, or allow others to do so, for the United States Government purposes. 


\section{DISCLAIMER}

This work was prepared as an account of work sponsored by an agency of the United States Government. Neither the United States. Government nor any agency thereof, nor any of their employees, nor any of their contractors, subcontractors or their employees, makes any warranty, express or implied, or assumes any legal liability or responsibility for the accuracy, completeness, or any third party's use or the results of such use of any information, apparatus, product, or process disclosed, or represents that its use would not infringe privately owned rights. Reference herein to any specific commercial product, process, or service by trade name, trademark, manufacturer, or otherwise, does not necessarily constitute or imply its endorsement, recommendation, or favoring by the United States Government or any agency thereof or its contractors or subcontractors. The views and opinions of authors expressed herein do not necessarily state or reflect those of the United States Government or any agency thereof. 


\title{
STATE-OF-THE-ART ELECTRON GUNS AND INJECTOR DESIGNS FOR ENERGY RECOVERY LINACS (ERL)*
}

\author{
A. M. M. Todd", A. Ambrosio, H. Bluem, V. Christina, M. D. Cole, M. Falletta, D. Holmes,
} E. Peterson, J. Rathke, T. Schultheiss, R. Wong, Advanced Energy Systems, Medford, NY, USA; S. Benson, E. Daly, D. Douglas, F. Dylla, W. Funk, C. Hernandez-Garcia, J. Hogan, P. Kneisel, J. Mammosser, G. R. Neil, L. Phillips, J. Preble, R. Rimmer, C. Rode, T. Siggins, T. Whitlach, M. Wiseman, TJNAF, Newport News, VA, USA; I. Ben-Zvi, A. Burrill, R. Calaga, P. Cameron, X. Chang, H. Hahn, D. Kayran, J. Kewisch, V. Litvinenko, G. McIntyre, A. Nicoletti, J. Rank, J. Scaduto, T. Srinivasan-Rao, K. Wu, A. Zaltsman, Y. Zhao, BNL, Upton, NY, USA; P. Colestock, J. P. Kelley, S. Kurennoy, D. Nguyen, S. Russell, W. Reass, D. Rees, D. Schrage, R. Wood, Los Alamos National Laboratory Alamos, NM, USA; R. Campisi, ORNL, Oakridge, TN, USA; D. Janssen, FZR, Dresden, Germany; J. W. Lewellen, ANL, Argonne, IL, USA; V. Nguyen-Tuong, Tunnel Dust, Newport News, VA, USA; J. Sekutowicz, DESY, Hamburg, Germany; and L. Young, TechSource, Santa Fe, NM, USA.

\section{Abstract}

A key technology issue of energy recovery linac (ERL) devices for high-power free-electron laser (FEL) and fourth generation light sources is the demonstration of reliable, high-brightness, high-power injector operation. Three ongoing programs that target up to 0.5 Ampere photocathode injector performance with required ERL brightness, are described. The first is a DC gun and superconducting RF (SRF) booster cryomodule. Such a $748.5 \mathrm{MHz}$ device is being assembled and will be tested up to $100 \mathrm{~mA}$ at the Thomas Jefferson National Accelerator Facility (JLAB) beginning in 2006. The second approach is a high-current normal-conducting RF (NCRF) injector. A $700 \mathrm{MHz}$ gun will undergo thermal test in late 2005 at the Los Alamos National Laboratory (LANL), which when equipped with a suitable cathode, would be capable of exceeding 0.5 Ampere operation. Finally, a half-cell $703.75 \mathrm{MHz}$ SRF gun with a diamond amplifier and other cathodes, will be tested to 0.5 Ampere at the Brookhaven National Laboratory (BNL) in 2007. The status and projected performance for each of these injector projects is presented.

\section{INTRODUCTION}

When we consider future ERL high-current projects that are under construction or have been proposed, we find similar "requirements" for their photocathode injectors [1]. Table 1 shows resultant "mean" values for the principal injector parameters, together with an associated range. It is also apparent that three injector technologies are being considered for ERL facilities, namely: DC, NCRF and SRF guns that will likely be followed by SRF boosters. Below, we describe the status of one example of each high-current injector technology.

\footnotetext{
* This work is supported by the Naval Sea Systems Command, the Office of Naval Research, the DOD Joint Technology Office, the Missile Defense Agency and the US Department of Energy.

\# alan todd@mail.aesys.net
}

Table 1: ERL injector nominal values and range

\begin{tabular}{|c|c|c|}
\hline Parameter & Nominal & Range \\
\hline Output Energy (MeV) & $\sim 7$ & $2-15$ \\
\hline CW Average Current (mA) & $\sim 200$ & $100-500$ \\
\hline Bunch Charge (nC) & $\sim 0.5$ & $0.075-3$ \\
\hline Transverse rms Normalized Emittance $(\mu \mathrm{m})$ & $\sim 1.5$ & $<1-6$ \\
\hline Longitudinal rms Emittance (keV-psec) & $<45$ & $25-145$ \\
\hline Bunch Length (psec) & $\sim 4$ & $2-7$ \\
\hline Energy spread (\%) at Injection & $<0.5$ & $0.1-0.5$ \\
\hline RF Frequency (MHz) & $\sim 700$ & $500-1300$ \\
\hline RF Feedthrough Power (kW) & $<500$ & $50-500$ \\
\hline Photocathode Frequency Response & Visible & Visible \\
\hline
\end{tabular}

\section{GUN AND SRF BOOSTER}

The present leading candidate for high-average-current ERL injectors is a DC photocathode gun closely coupled to an SRF booster accelerator. One such device has been designed and fabricated by Advanced Energy Systems (AES) and is presently being assembled at $\mathrm{LAB}$ for testing on their injector test stand.

The device begins with a $500 \mathrm{kV}$ DC gun followed by an emittance compensation solenoid. The electron beam enters the $748.5 \mathrm{MHz}$ SRF cryomodule, shown in Fig. 1, from the left. This consists of three single cell fundamental cavities and one $2245.5 \mathrm{MHz}$ third harmonic cavity that accelerate the beam to $7 \mathrm{MeV}$. The third harmonic cavity is the second cell in the string, whose function is to linearize the longitudinal phase space on exit from the cryostat. The addition of the longitudinal phase space correction cavity significantly improves the beam quality in these injectors. Specifically at $1 \mathrm{nC}$ or $0.75 \mathrm{~A}$, this configuration can deliver 5.1 microns transverse and $43 \mathrm{keV}$-psec longitudinal rms emittance at $7 \mathrm{MeV}$, which is more than adequate for very high-power IR FEL operation.

When every RF bucket is filled with $133 \mathrm{pC}$, the single cell device provides an average current of $100 \mathrm{~mA}$ and an average electron beam power of $700 \mathrm{~kW}$ at the $7 \mathrm{MeV}$ injector output. The sequence of single cell cavities provides latitude for adjusting the longitudinal phase space through different cavity phasing and ameliorates HOM and wakefield effects driven by high current. 


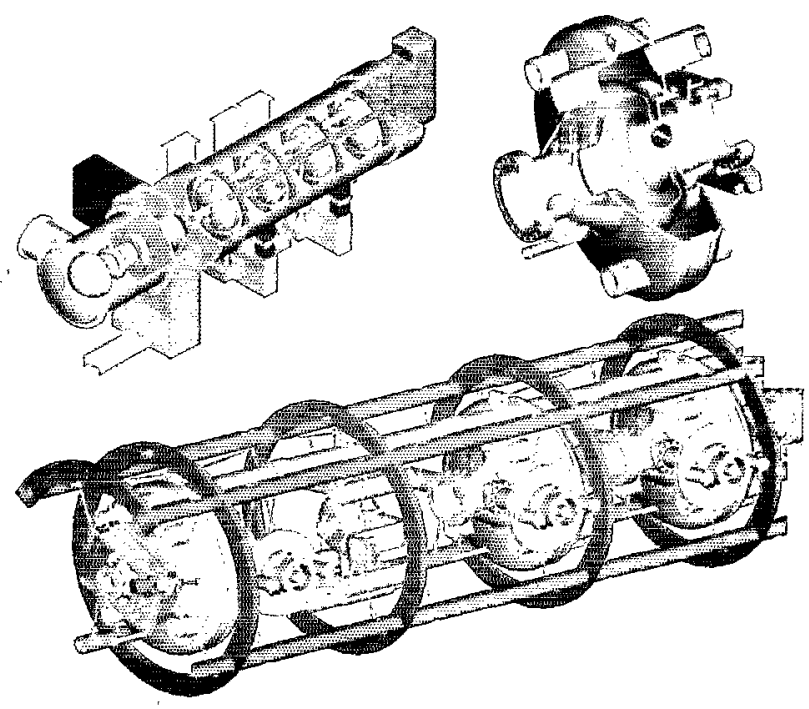

Figure 1: DC Gun and SRF booster (upper left) showing $3^{\text {rd }}$ harmonic (lower) and fundamental cavity (upper right).

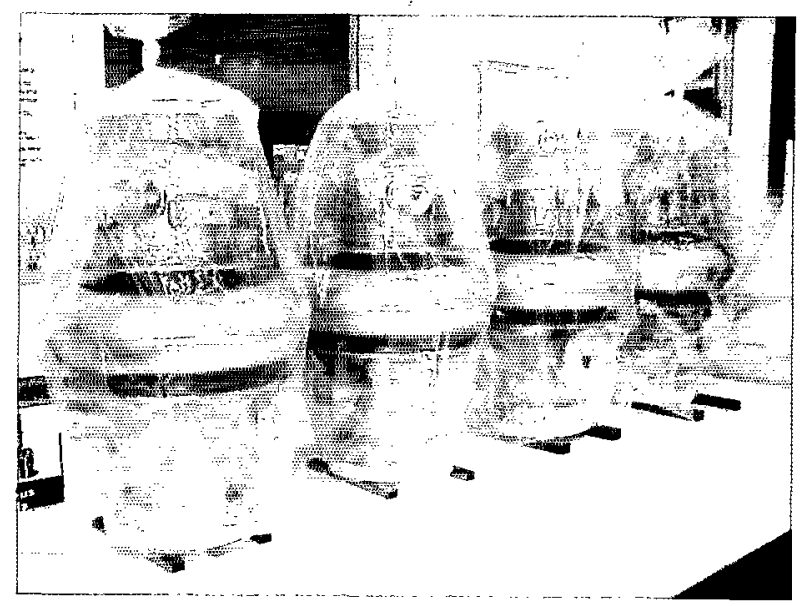

Figure 2: Four 748.5 MHz SRF fundamental cavities.

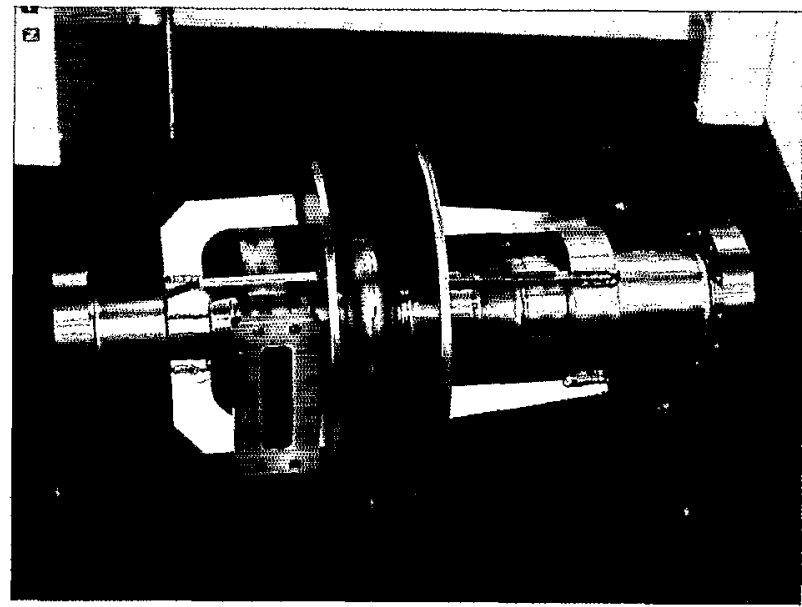

Figure 3: $2245.5 \mathrm{MHz}$ third harmonic SRF cavity.

Fig. 2 shows four completed single-cell SRF cavities, while Fig. 3 shows the $3^{\text {rd }}$ harmonic cavity, all minus their helium vessels. Cavity cleaning has begun at $J \mathrm{LAB}$ with assembly scheduled for completion by the end of 2005 .
Initial beam tests in 2006 will demonstrate bunch charges up to $1 \mathrm{nC}$ at low pulse repetition frequency (PRF), with later RF power upgrades enabling $100 \mathrm{~mA}$ characterization in 2008 .

\section{NORMAL-CONDUCTING RF GUN}

The second high-power injector approach that is under development at AES is the normal-conducting, $\mathrm{CW}$, photocathode RF electron gun that is shown in Fig. 4. Los Alamos performed the physics and RF design for this $700 \mathrm{MHz}, 2 \frac{1}{2}$-cell, $3 \mathrm{nC}$ device that delivers $100 \mathrm{~mA}$ at a $35 \mathrm{MHz}$ PRF. Higher currents could be delivered without impacting the gun thermal or beam properties, simply by increasing the PRF. A third full cell does not support acceleration but rather serves as a vacuum manifold to permit very high pumping on the gun during operation. The crucial issue for this concept is the extremely highaverage-power and the peak power densities that result from the resistive losses in the copper of the gun.

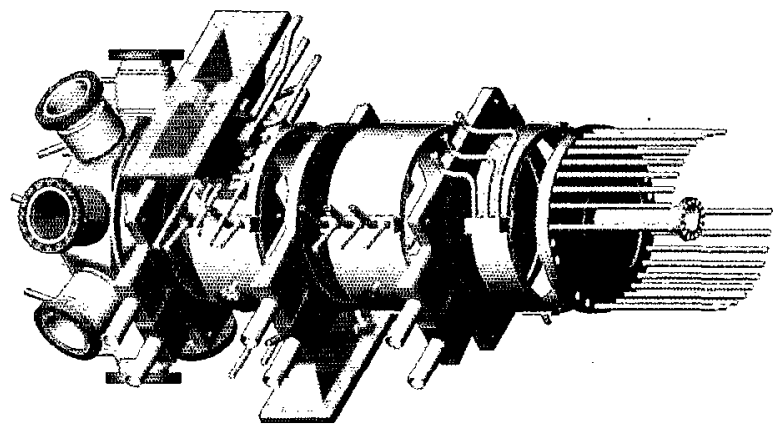

Figure 4: Normal-conducting 21/2-cell CW RF gun.

Thermal, stress, and displacement analyses were conducted on the gun design where the effects of temperature and pressure coupled with the RF response were all taken into account. The thermal stresses are such that the gun is manufactured from Glidcop ${ }^{\circledR}$. The total thermal load of the gun is about $720 \mathrm{~kW}$, but the design

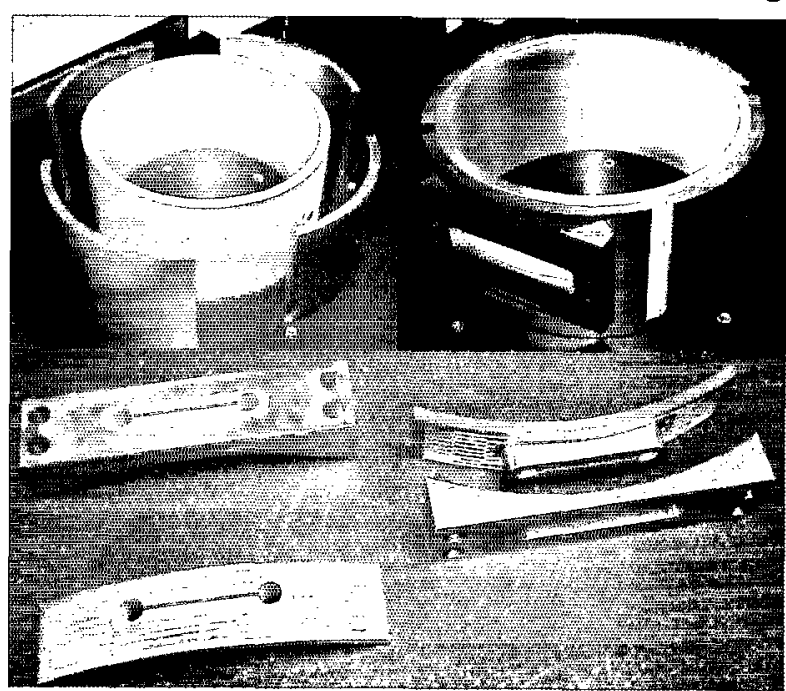

Figure 5: NCRF gun cell 2 (upper left) and cell 3 (upper right) plated and ready for brazing. Waveguide irises machined and ready for plating (lower). 
coolant flow will adequately cool the device.

Fig.5 shows two of the gun cells plated and ready for brazing. One of the ridge-loaded waveguide penetrations is visible on cell 3. It also shows the "dogbone" iris of the power coupler which is a critical thermal and braze point. This gun represents one of the most complex brazing cycles that has ever been attempted. Currently, we are $25 \%$ complete on the braze cycle. The gun is scheduled for delivery to Los Alamos for testing in late 2005. An existing Los Alamos $1 \mathrm{MW}$ RF test stand will be used to perform a thermal test of the gun at the end of 2005 . Beam tests up to about $200 \mathrm{~mA} \mathrm{CW}$ could be performed in 2006 at reduced accelerating gradient with $1 \mathrm{nC}$ bunches and $200 \mathrm{MHz}$ PRF using the existing LANL RF power, once a preparation chamber and load lock are added to the gun to permit multi-alkali cathode insertion.

\section{SUPERCONDUCTING RF GUN}

The third injector under development at AES in collaboration with BNL, JLAB and FZR is the highcurrent SRF gun shown in Fig. 6. This gun is being designed and fabricated to deliver $0.5 \mathrm{~A}$ to the ERL test ring that is being built at BNL [1]. The high current requires a substantial departure from the FZR 31/2-cell design at $1.3 \mathrm{GHz}$ [2]. Firstly, we have adopted a $1 / 2$-cell gun configuration at the lower frequency of $703.75 \mathrm{MHz}$, which is compatible with the RHIC RF frequency, in order to accommodate the higher currents required for the RHIC electron cooling rings and the e-RHIC collider. Secondly, primarily because of thermal issues, we determined to utilize a quarter wave choke joint concept [3]. This is shown in Fig. 7 to the left of the $1 / 2$ cell cavity.

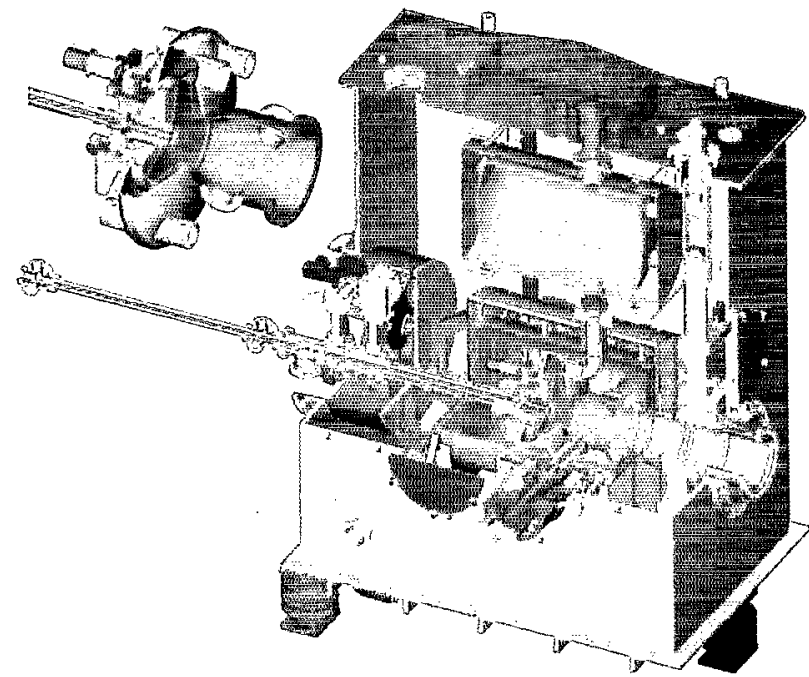

Figure 6: SRF gun cryostat and cavity detail (upper left).

Thermal and stress analyses of this SRF gun with the choke joint have been completed. For 0.5 A operation, the thermal load on the cathode stalk, which is cooled with liquid nitrogen, is between 150 and $180 \mathrm{~W}$, depending on whether a multi-alkali or diamond amplifier cathode [4] is employed. We have completed multipactor testing of the choke concept and demonstrated performance to $150 \%$ of the nominal field value.

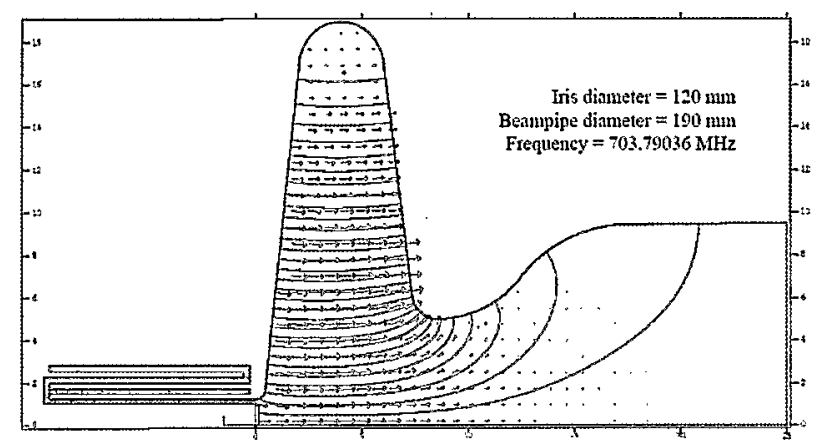

Figure 7: SRF gun choke joint and $1 / 2$ cell cavity.

This injector is presently in the final design phase. Delivery to BNL is planned for early 2007 . Initial gun performance testing will therefore occur in 2007.

\section{CONCLUSIONS}

The performance of three distinct high-current ERL injector technologies, which are under development at AES in partnership with National Laboratories, is listed in Table 2. The impact of harmonic correction, which is important for each technology, is shown in parentheses only for the SRF gun, and each requires further beam tailoring for ERL merging. The $100 \mathrm{~mA} \mathrm{DC}$ gun with an SRF booster is presently being assembled at $\mathrm{LAB}$ for testing beginning in 2006. The normal-conducting gun is in fabrication for delivery to LANL in late 2005. It will undergo thermal testing equivalent to beam operation at 1 $A$ in early 2006. Finally, the SRF gun, which will be installed on the BNL test ERL is in final design. Operation testing of this gun to $0.5 \mathrm{~A}$ will occur in 2007.

Table 2: AES ERL injector parameters

\begin{tabular}{|l|c|c|c|}
\hline DEVICE & $\begin{array}{c}\text { AES/JLAB } \\
\text { Injector }\end{array}$ & $\begin{array}{c}\text { LANL/AES } \\
\text { Gun }\end{array}$ & $\begin{array}{c}\text { AES/BNL } \\
\text { Gun/ERL }\end{array}$ \\
\hline PARAMETER & DC & NCRF & SRF \\
RF Frequency (MHz) & 748.5 & 700 & 703.75 \\
PRF (MHz) & 748.5 & 33.3 & 351.88 \\
Charge/Bunch (nC) & 0.133 & 3.0 & 1.4 \\
Current (mA) & 100 & 100 & 500 \\
Injector Energy (MeV) & 7 & 2.5 & 2 \\
Mean Accelerating Gradient (MV/m) & $7 / 13.5$ & 7 & 23.5 \\
Transverse rms Normalized Emittance ( $\mu \mathrm{m})$ & 1.2 & 6 & 2.5 \\
Longitudinal rms Emittance (keV-psec) & 44 & 145 & $64(19)$ \\
RMS Bunch Length (psec) & 6.3 & & 15.4 \\
RMS Energy Spread (\%) & 0.5 & 0.5 & $2.1(1.7)$ \\
\hline
\end{tabular}

\section{REFERENCES}

[1] Proceedings of the 32nd Advanced ICFA Beam Dynamics Workshop on Energy Recovering Linacs, to appear in NIMA, March 18-23, 2005, Newport News, VA, USA.

[2] D. Janssen et al., "Status of the $31 / 2$ Cell Rossendorf Superconducting RF Gun," Proc. FEL 2004, ISBN 88-87992-02-9, Trieste, Italy (2004) 359-362.

[3] V. Nguyen-Tuong, L. Phillips and J. Preble for Tunnel Dust, Inc., priv. comm.

[4] T. Rao et al., "Diamond Amplifier for Photocathodes," AIP Conf. Proc. 737 (2004) 178. 